\title{
Time and regional perspectives of food insecurity during the economic crisis in Portugal, 2011-2013
}

\section{Perspectivas temporais e regionais da insegurança alimentar durante a crise econômica em Portugal, 2011-2013}

\author{
Maria João Gregório \\ Graduate in Nutritional Sciences. Currently in the Doctorate pro- \\ gram at the School of Nutrition and Food Sciences of the University \\ of Porto. Invited Assistance at the School of Nutrition and Food \\ Sciences of the University of Porto. \\ E-mail: mariajoaobg®fcna.up.pt \\ Pedro Graça \\ Doctor of Human Nutrition. Associate Professor at the School of \\ Nutrition and Food Sciences of the University of Porto. Director of \\ National Program for the Promotion of Healthy Eating, Directorate- \\ General of Health. \\ E-mail: pedrogracaœdgs.pt

\section{Andreia Costa} \\ Doctor by the Universidade Católica Portuguesa. Diretor of the Di- \\ rectorate of Disease Prevention and Health Promotion. Directorate- \\ - General of Health. \\ E-mail: andreiasilvaœdgs.pt

\section{Paulo Jorge Nogueira} \\ Doctor in International Health (Health and Development Policies), \\ Auxiliar Professor at Instituto de Medicina Preventiva e Saúde \\ Pública, Faculdade de Medicina da Universidade de Lisboa; Direc- \\ tor of National Services of Analysis and Information, Directorate- \\ -General of Health. \\ E-mail: paulo.nogueiraळdgs.pt

\section{Correspondence} \\ Paulo Jorge Nogueira \\ D. Afonso Henriques, 45, CEP 1049-005, Lisboa, Portugal.
}

\section{Abstract}

Food insecurity (FI) has received much attention in recent years, even in high-income countries, due to the increasing trend of poverty and social inequalities indicators, as a result of the global financial crisis. The establishment of a monitoring system of FI becomes a priority for food and nutrition policies. Our study aims to evaluate FI trends during the economic crisis in Portugal and to identify regional disparities throughout the country. Data derived from three surveys conducted by the Portuguese Directorate-General of Health, concerning FI of the Portuguese population, during the period that Portugal was under the International Monetary Fund financial assistance program (2011-2013). Data were collected by face-to-face interviews and FI was evaluated using a psychometric scale. Logistic regression models were used to identify regional disparities in FI. The prevalence of FI was relatively unchanged at national and regional levels, during the analysis period. Data from 2013 indicates a high prevalence of FI (50.7\%), including $33.4 \%$ for low FI, $10.1 \%$ for moderate FI and $7.2 \%$ for severe FI. Disparities according health region were also found for household FI. Algarve, Lisboa and Vale do Tejo were the two regions with the highest levels of FI, even after controlling for other socioeconomic variables. High levels of FI found in Portugal and the different regional profiles suggest the need for regional strategies, in particular in the most affected regions based on a broader action with different policy sectors (health, social security, municipalities and local institutions in the field of social economy).

Keywords: Food Insecurity; Economic Crisis; Portugal; Regional Disparities. 


\section{Resumo}

As questões da insegurança alimentar (IA) têm merecido uma atenção crescente nos últimos anos, mesmo nos países desenvolvidos, considerando a tendência crescente dos indicadores de pobreza e de desigualdades sociais, em resultado da crise económica global. A implementação de um sistema de monitorização da IA tornou-se uma prioridade das políticas de alimentação e nutrição. Este estudo pretende avaliar as tendências da IA durante a crise económica em Portugal, identificando possíveis iniquidades regionais. Os dados analisados provêm de três inquéritos conduzidos pela Direção-Geral da Saúde, referentes à IA da população portuguesa, durante o período em que Portugal esteve sob intervenção do programa de assistência financeira do Fundo Monetário Internacional (2011-2013). Os dados foram recolhidos por entrevistas face-a-face e a IA avaliada através de uma escala psicométrica. Utilizaram-se modelos de regressão logística para identificar iniquidades regionais na IA. A prevalência de IA manteve-se relativamente inalterada, a nível nacional e regional, durante este período. Em 2013 verificou-se uma elevada prevalência de IA $(50,7 \%)(33,4 \%$ IA leve, $10,1 \%$ IA moderada e $7,2 \%$ IA grave). Iniquidades regionais foram também encontradas para a IA. As regiões do Algarve e de Lisboa e Vale do Tejo foram as que apresentaram níveis de IA mais elevados, mesmo após ajuste para as variáveis socioeconómicas. Os níveis de IA em Portugal e as disparidades regionais encontradas sugerem a necessidade de implementar estratégias a nível regional, em particular nas regiões mais afetadas, envolvendo os diferentes sectores com capacidade interventiva (saúde, segurança social, autarquias, instituições locais na área da economia social).

Palavras-chave: Insegurança Alimentar; Crise Econômica; Portugal; Iniquidades Regionais.

\section{Introduction}

Food insecurity (FI) has received much attention in recent years, even in high-income countries, due to the increasing trend of poverty and social inequalities indicators, as a result of the global financial crisis. Facing the current economic crisis, the austerity programmes implemented by the Portuguese government and imposed by International Monetary Fund (IMF) may lead to negative impacts in inequality and poverty levels. Despite the fact that Portugal was already on the top of the most unequal countries in the Organization for Economic Cooperation and Development (OECD), the last European Union Statistics on Income and Living Conditions (EU-SILC), showed that the financial crisis accelerated the income inequality and poverty. EU-SILC data showed that $18.7 \%$ of Portuguese population was at-risk-of-poverty in 2012. With regards to income inequalities indicators, Portugal has seen increases in its income inequality ( $\left.\mathrm{S} 8 \mathrm{O} / \mathrm{S}_{2} \mathrm{O}\right)$ of almost 0.4 percentage points during $2009-12$. The $20 \%$ of the population with the highest equalised disposable income received 6.o times as much income as the $20 \%$ of the population with the lowest equalised disposable income. Moreover, the Gini coefficient also increased 0.5 percentage points, during the same period and in 2012 this indicator for Portugal was $34.2 \%$ (Portugal, 2014). A reduction in the median equalised disposable income was also seen in Portugal during the economic crisis, it felt by $4.4 \%$ between 2009 and 2010 (Di Meglio, 2013). Furthermore, high unemployment rates found in Portugal are a big concern as a reflexion of the financial crisis and its austerity measures (Eurostat, 2013). In addition, extensive cuts in Portugal's government budget for public services such as education, health and social security were induced by the financial crisis and its austerity programs implemented (Cavero and Poinasamy, 2013).

Not surprisingly, periods of economic, political and social instability tend to greatly affect the population's diet (Dore et al., 2003) and lead to FI situations among the most disadvantaged population groups. Indeed, it is expected that all of these accelerating social and economic changes, that are currently occurring, might have a direct and relevant 
impact in food security of Portuguese households and consequently with relevant impacts on populations' health and nutritional status.

Additionally, there is growing evidence suggesting the existence of a consistent and growing up social gap in obesity and other diet-related non-communcable diseases (Drewnowski, 2009; Robertson, 2001; Singh et al., 2010), which are already the leading cause of death and disease in Western societies (WHO (Europe), 2013a). In fact, there is strong evidence that underprivileged people, who commonly live in FI conditions, have a higher risk of poor health (Marmot and Wilkinson, 2005; Stuff et al., 2004). Different studies have found an association between socioeconomic status and health, in which socioeconomically vulnerable groups experience higher mortality and morbidity rates for coronary heart disease (Rooks et al., 2002), atherosclerosis, Type 2 diabetes mellitus (Evans et al., 200o), some cancers (Ward et al., 2004) and obesity (Robertson et al., 2007; Sobal and Stunkard, 1989). Moreover, social inequalities have been also associated with two of the main risk factors for obesity and other diet-related non-communicable diseases - unhealthy dietary habits and lower levels of physical activity - which also seem to be more common in lower socioeconomic groups (Darmon and Drewnowski, 2008).

Actually, at international level, the guarantee of food security, which was defined in 1996 by the World Food Summit as a situation that exists "when all people at all times have access to sufficient, safe and nutritious food to maintain a healthy and active life" (World Food Summit, 1996), becomes a priority action for food and nutrition policies. The most recent European Food and Nutrition Action Plan 2015-2020 published by World Health Organization (WHO) Regional Office for Europe, pointed, for the first time, the importance of the food security guarantee in its mission - "to achieve universal access to affordable, balanced, healthy food, with equity and gender equality in nutrition for all citizens of the WHO European Region through intersectoral policies" (WHO (Europe), 2013b). Furthermore, tackling socioeconomic inequalities in health has been recognised in many others global and European policy documents as one of the main challenges for public health (CEC, 2007; WHO (Europe), 2012, 2013a).
Few studies have been conducted in Portugal regarding FI situation. The most recent study estimates a prevalence of $16.7 \%$ for FI between 2005 and 2006 (Álvares, 2013). However, monitoring FI becomes a priority strategy of a national food and nutrition action plan, even more in times of crisis. Since 2011, Portugal had implemented a monitoring system of FI aimed at collecting data on FI of the Portuguese population in a regular and systematically way. Data collected by this survey concerned to the three-year period that Portugal was under the IMF financial assistance program. To our knowledge, FI could be a good indicator to monitor the impact of socioeconomic changes in populations' diet, in order to provide a basis for planning public health actions and targeting decisions to minimize the health impacts of the financial crisis.

This study aims to evaluate trends in FI prevalence during the economic crisis in Portugal and to identify regional disparities throughout the country.

\section{Methods}

Data were derived from the national FI survey in Portugal - INFOFAMÍLIA Survey - conducted by the Directorate-General of Health. INFOFAMÍLIA survey is a cross-sectional study in a sample of users of primary health care. A systematic random sampling was performed, in which one in five individuals aged more than 18 years old that resorted to the national health system (Health Centres) was recruited, during the collection periods. Data were collected using face-to-face interviews by nurses in primary health care and household FI was assessed using a psychometric scale adapted from the Brazilian Food Insecurity Scale (IBGE, 2010). This tool measures both the quantitative and qualitative components of FI during the last three months. A score ranging from o to 14 was obtained as a result of the total number of affirmative responses. According to this score, households were classified in four different categories of household FI, as presented in table 1. Data collected included socioeconomic and demographic characterization, including both household and individual variables. This paper analyses and compares data from different collection periods of the INFOFAMÍLIA Survey (2011, 2012 and 2013) 
(Graça et al., 2013). In 2011, 2012 and 2013 a sample of 1178,1208 , and 1382 households were respectively collected. Since these data were part of the official statistics, didn't collect personal identification data and that this research didn't include any kind of intervention, no approval from an ethics committee was requested. Although appropriate information regarding the present study was given to participants and verbal consent was received. The anonymity and confidentiality of the data provided by participants were also guaranteed.

Data were analysed using IBM SPSS statistical software version 21. Descriptive analysis was undertaken to determine prevalence of FI in Portugal, as well as among health regions (Norte, Centro, Lisboae Vale do Tejo, Alentejo e Algarve) (Figure 1). Chi-square tests were used to assess bivariate associations.
Logistic regression was conducted to estimate the association between FI and health region, controlling for sociodemographic characteristics (Odds Ratio (OR) and 95\% CI). Our adjusted logistic regression models included: respondent's age, sex of the respondent, highest level of respondent's education, occupational status of the respondent, respondent's nationality, presence of children in household, family size and number of household members with income. For logistic regression analysis, moderate and severe categories of household FI were combined to increase the statistical power of our data. To compare data from different INFOFAMÍLIA survey collection periods, data sets from 2011, 2012 and 2013 were merged. Results were considered statistically significant if p-value was under 0.05, and if below 0.001 they were considered highly statistical significant.

\section{Table I - Definition of Food Insecurity levels}

\begin{tabular}{|l|l|}
\hline Food Security Level & Definition \\
\hline Food Security & Households show access at all times to enough food for an active and healthy life. \\
\hline Low Food Insecurity & $\begin{array}{l}\text { Households reported at least anxiety about lack of food to meet dietary needs. At this level, coping } \\
\text { strategies to deal with economic and food constraints can also have an impact on the reduction of } \\
\text { diet quality. }\end{array}$ \\
\hline Moderate Food Insecurity & $\begin{array}{l}\text { Adults in the household reported food intake reduction and changes in eating patterns due to } \\
\text { economic difficulties in accessing food. }\end{array}$ \\
\hline Severe Food Insecurity & $\begin{array}{l}\text { At this level, households without children experienced the physical sensation of hunger and } \\
\text { households with children reported a reduction of children's food intake. }\end{array}$ \\
\hline
\end{tabular}

Figure I - Health regions of Portugal country

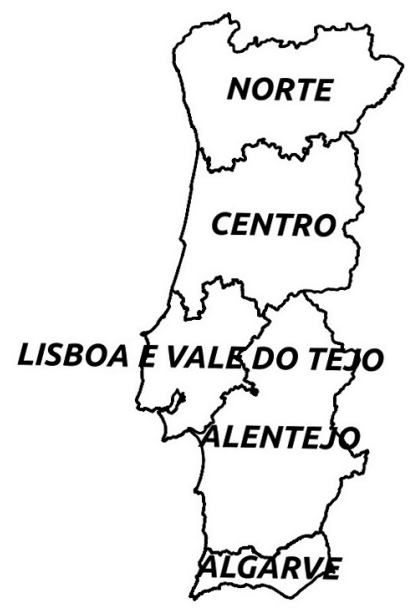

\section{Results}

Between 2011 and 2013, prevalence of FI was essentially unchanged and in 2013 the prevalence of FI remained at $50.7 \%$. From those food-insecure households, $33.4 \%$ were in low FI, $10.1 \%$ in moderate FI and $7.2 \%$ in severe FI (Figure 2). Comparing data from the three years of analysis, statistical differences were found for Algarve Region in the overall level of FI. A significant increase was observed between 2011 and 2012 (20.2 percentage points). However, this prevalence has decreased between 2012 and 2013 (-17.6 percentage points). In this region, the same trend was observed for the most severe level of FI. Between 2011 and 2012 a significant increase was 
observed (28.5 percentage points) and at the same time a significant decrease ( -26.8 percentage points) between 2012 and 2013.

For the national average, a decrease in moderate FI prevalence was found between 2011 and 2012 (3.0 percentage points) and an increase in severe
FI prevalence (2.4 percentage points) during the same period of analysis. For the most severe levels of FI, statistical differences were also found for the Alentejo region. Between 2011 and 2012 a significant decrease in the prevalence of FI was observed (-7.9 percentage points) (Table 2).

Table 2 - Food Insecurity prevalence in Portugal by health region, during 2011-2013

\begin{tabular}{|c|c|c|c|c|c|c|c|c|c|c|c|c|}
\hline & \multicolumn{6}{|c|}{ Food Insecurity } & \multicolumn{6}{|c|}{ Low Food Insecurity } \\
\hline Region & 2011 & 2012 & 2013 & $\begin{array}{l}\text { Change } \\
2011-2012\end{array}$ & $\begin{array}{c}\text { Change } \\
2012-2013\end{array}$ & $\begin{array}{l}\text { Change } \\
2011-2013\end{array}$ & 2011 & 2012 & 2013 & $\begin{array}{l}\text { Change } \\
2011-2012\end{array}$ & $\begin{array}{l}\text { Change } \\
2012-2013\end{array}$ & $\begin{array}{l}\text { Change } \\
2011-2013\end{array}$ \\
\hline National Average & 48.6 & 49.1 & 50.7 & 0.5 & 1.6 & 2.1 & 31.0 & 32.1 & 33.4 & 1.1 & 1.3 & 2.4 \\
\hline Alentejo & 42.5 & 43.8 & 46.5 & 1.3 & 2.7 & 4 & 23.3 & 27.7 & 31.4 & 4.4 & 3.7 & 8.1 \\
\hline Algarve & 56.9 & 77.1 & 59.5 & $20.2^{*}$ & $-17.6^{*}$ & 2.6 & 31.1 & 18.8 & 31.7 & -12.3 & 12.9 & 0.6 \\
\hline Centro & 44.7 & 45.5 & 50.0 & 0.8 & 4.5 & 5.3 & 34.1 & 34.0 & 39.2 & -0.1 & 5.2 & 5.1 \\
\hline LVT & 51.7 & 58.6 & 57.9 & 6.9 & -0.7 & 6.2 & 33.2 & 30.5 & 37.9 & -2.7 & 7.4 & 4.7 \\
\hline \multirow[t]{2}{*}{ Norte } & 46.0 & 49.1 & 50.7 & 3.1 & 1.6 & 4.7 & 28.3 & 32.1 & 28.4 & 3.8 & -3.7 & 0.1 \\
\hline & \multicolumn{6}{|c|}{ Moderate Food Insecurity } & \multicolumn{6}{|c|}{ Severe Food Insecurity } \\
\hline Region & 2011 & 2012 & 2013 & $\begin{array}{l}\text { Change } \\
2011-2012\end{array}$ & $\begin{array}{l}\text { Change } \\
2012-2013\end{array}$ & $\begin{array}{l}\text { Change } \\
2011-2013\end{array}$ & 2011 & 2012 & 2013 & $\begin{array}{l}\text { Change } \\
2011-2012\end{array}$ & $\begin{array}{l}\text { Change } \\
2012-2013\end{array}$ & $\begin{array}{l}\text { Change } \\
2011-2013\end{array}$ \\
\hline National Average & 11.2 & 8.2 & 10.1 & $-3.0^{*}$ & 1.9 & -1.1 & 6.4 & 8.8 & 7.2 & $2.4^{*}$ & -1.6 & 0.8 \\
\hline Alentejo & 14.2 & 6.3 & 10.5 & $-7.9^{*}$ & 4.2 & -3.7 & 5.0 & 9.8 & 4.7 & 4.8 & -5.1 & -0.3 \\
\hline Algarve & 12.6 & 16.7 & 12.7 & -4.1 & -4.0 & 0.1 & 13.2 & 41.7 & 15.1 & $28.5^{* *}$ & $-26.6^{* *}$ & 1.9 \\
\hline Centro & 6.2 & 5.8 & 7.2 & -0.4 & 1.4 & 1.0 & 4.4 & 5.8 & 3.6 & 1.4 & -2.2 & -0.8 \\
\hline LVT & 12.4 & 10.7 & 12.5 & -1.7 & 1.8 & 0.1 & 6.1 & 7.7 & 7.5 & 1.6 & -0.2 & 1.4 \\
\hline Norte & 12.5 & 8.6 & 9.9 & -3.9 & 1.3 & -2.6 & 5.1 & 7.9 & 6.8 & 2.8 & -1.1 & 1.7 \\
\hline
\end{tabular}

${ }^{*} P<0.05,{ }^{* *} P<0.001$

$P$ value according to the Chi-square tests.

Figure 2 - Trends in Food Insecurity prevalence in Portugal between 2011 and 2013

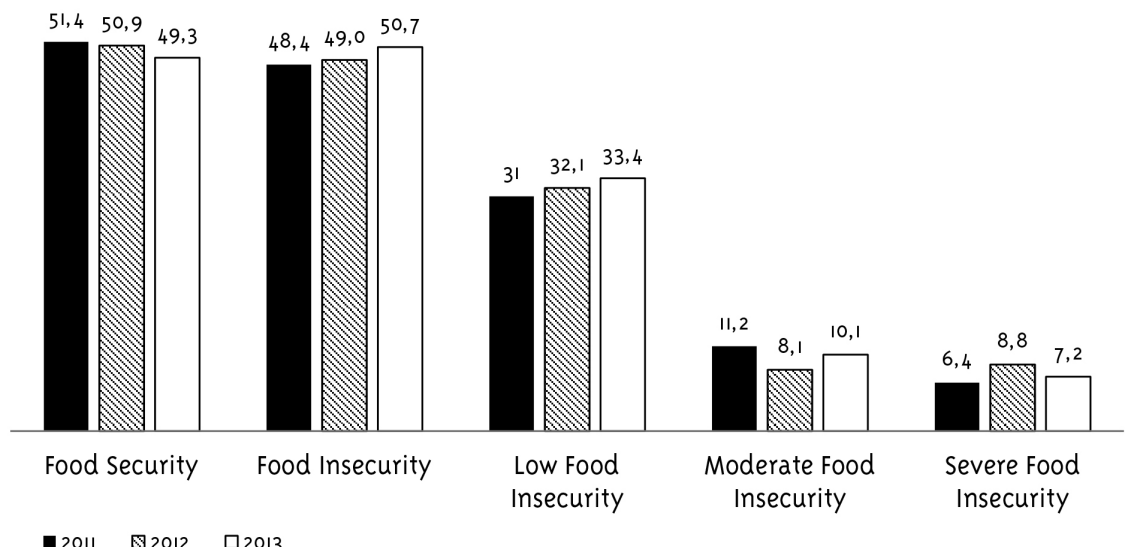


Furthermore, differences were found, for the health-regions, in FI prevalence through these three years. In 2011, household FI ranges by regions from $42.5 \%$ in the Alentejo to $56.9 \%$ in the Algarve. The prevalence of FI was significantly lower than the national average in Alentejo (42.5\%), Centro (44.6\%) and Norte (48.4\%). On the other hand, FI was significantly higher than the national average in the Algarve (56.9\%) and Lisboa and Vale do Tejo (51.7\%). When analysing the differences in FI by categories, among Portugal regions, statistical differences were found for moderate and severe level of FI and a significantly higher prevalence was found in Algarve (13.2\%), when comparing with the national average (Table 3). In 2012, household FI ranged across regions from $43.8 \%$ in Alentejo to $77.1 \%$ in Algarve. The prevalence of FI was significantly lower than the national average in Alentejo (43.8\%), Centro (45.5\%) and Norte (47.0\%) and, was significantly higher in
Algarve (77.1\%) and Lisboa e Vale do Tejo (58.6\%). Differences across regions were also found for low and severe FI. For low FI, a significantly higher prevalence than the national average was found in Lisboa and Vale do Tejo (40.2\%) and in Centro (34.0\%) and, a significantly lower prevalence was found in Algarve (18.8\%), Alentejo (27.7\%) and Norte (30.5\%). For severe FI a significantly higher prevalence when comparing with the national average was found in Algarve (41.7\%) and in Alentejo (9.8\%). For the other health regions, the prevalence of severe FI was significantly lower than the national average (Table 4). In 2013, household FI ranged across regions from $45.1 \%$ in Norte to $59.5 \%$ in Algarve. The prevalence of FI was significantly lower than the national average in Alentejo (46.5\%), Centro (50.0\%) and Norte (50.7\%) and, was significantly higher in Algarve (59.5\%) and Lisboa and Vale do Tejo (57.9\%). Differences across regions were also found for low and severe FI.

\section{Table 3 - Food Insecurity prevalence in Portugal by health region in $2011 \quad(n=1178)$}

\begin{tabular}{lccccccccccc} 
& \multicolumn{2}{c}{ Food Security } & \multicolumn{2}{c}{ Food Insecurity } & \multicolumn{2}{c}{ Low Food Insecurity } & \multicolumn{2}{c}{ Moderate Food Insecurity } & Severe Food Insecurity \\
& $\%(n)$ & $95 \% \mathrm{Cl}$ & $\%(n)$ & $95 \% \mathrm{Cl}$ & $\%(n)$ & $95 \% \mathrm{Cl}$ & $\%(n)$ & $95 \% \mathrm{Cl}$ & $\%(n)$ & $95 \% \mathrm{Cl}$ \\
\hline Alentejo & $57.5 \%(69)$ & $48.1-66.4$ & $42.5 \%(51)$ & $33.5-51.8$ & $23.3 \%(28)$ & $16.1-31.9$ & $\mathbf{1 4 . 2 \% ( 1 7 )}$ & $8.5-21.7$ & $5.0 \%(6)$ & $1.9-10.6$ \\
Algarve & $43.1 \%(72)$ & $35.5-51.0$ & $56.9 \%(95)$ & $49.0-64.5$ & $31.1 \%(52)$ & $24.2-38.7$ & $\mathbf{1 2 . 6 \% ( 2 1 )}$ & $8.0-18.6$ & $13.2 \%(22)$ & $8.4-19.3$ \\
Centro & $55.3 \%(151)$ & $49.2-61.3$ & $44.7 \%(122)$ & $38.7-50.8$ & $34.1 \%(93)$ & $28.5-40.0$ & $6.2 \%(17)$ & $3.7-9.8$ & $4.4 \%(12)$ & $2.3-7.6$ \\
LVT & $48.3 \%(167)$ & $42.9-53.7$ & $51.7 \%(179)$ & $46.3-57.1$ & $33.2 \%(115)$ & $28.3-38.5$ & $12.4 \%(43)$ & $9.1-16.4$ & $6.1 \%(21)$ & $3.8-9.1$ \\
Norte & $54.0 \%(147)$ & $47.9-60.2$ & $46.0 \%(125)$ & $39.9-52.1$ & $28.3 \%(77)$ & $23.0-34.1$ & $12.5 \%(34)$ & $8.8-17.0$ & $5.1 \%(14)$ & $2.8-8.5$ \\
Total & $51.4 \%(606)$ & $48.5-54.3$ & $48.6 \%(572)$ & $45.7-51.5$ & $31.0 \%(365)$ & $28.4-33.7$ & $11.2 \%(132)$ & $9.5-13.1$ & $6.4 \%(75)$ & $5.0-7.9$ \\
\hline$P$ value & $p=0.038$ & & $p=0.038$ & & $p=0.183$ & & $p=0.057$ & & $p=0.003$ \\
\hline
\end{tabular}

${ }^{*} P<0.05,{ }^{* *} P<0.001$

$P$ value according to the Chi-square tests.

Table 4 - Food Insecurity prevalence in Portugal by health region in $2012 \quad(n=1208)$

\begin{tabular}{lcccccccccc} 
& \multicolumn{2}{c}{ Food Security } & \multicolumn{2}{c}{ Food Insecurity } & \multicolumn{2}{c}{ Low Food Insecurity } & \multicolumn{2}{c}{ Moderate Food Insecurity } & \multicolumn{2}{c}{ Severe Food Insecurity } \\
& $\%(n)$ & $95 \% \mathrm{Cl}$ & $\%(n)$ & $95 \% \mathrm{Cl}$ & $\%(n)$ & $95 \% \mathrm{Cl}$ & $\%(n)$ & $95 \% \mathrm{Cl}$ & $\%(n)$ & $95 \% \mathrm{Cl}$ \\
\hline Alentejo & $56.3 \%(63)$ & $46.6-65.6$ & $43.8 \%(49)$ & $34.4-53.4$ & $27.7 \%(31)$ & $19.6-36.9$ & $6.3 \%(7)$ & $2.5-12.5$ & $9.8 \%(11)$ & $5.0-16.9$ \\
Algarve & $22.9 \%(11)$ & $12.0-37.3$ & $\mathbf{7 7 . 1 \% ( 3 7 )}$ & $62.7-87.8$ & $18.8 \%(9)$ & $8.9-32.6$ & $16.7 \%(8)$ & $7.5-30.2$ & $41.7 \%(20)$ & $27.6-56.7$ \\
Centro & $54.5 \%(189)$ & $49.1-59.8$ & $45.5 \%(158)$ & $40.2-50.9$ & $34.0 \%(118)$ & $29.0-39.3$ & $5.8 \%(20)$ & $3.6-8.8$ & $5.8 \%(20)$ & $3.6-8.8$ \\
LVT & $41.4 \%(70)$ & $33.9-49.2$ & $58.6 \%(99)$ & $50.8-66.1$ & $40.2 \%(68)$ & $32.8-48.0$ & $10.7 \%(18)$ & $6.4-16.3$ & $7.7 \%(13)$ & $4.2-12.8$ \\
Norte & $53.0 \%(282)$ & $48.7-57.3$ & $47.0 \%(250)$ & $42.7-51.3$ & $30.5 \%(162)$ & $26.6-34.6$ & $8.6 \%(46)$ & $6.4-11.4$ & $7.9 \%(42)$ & $5.7-10.5$ \\
Total & $50.9 \%(615)$ & $48.1-53.8$ & $49.1 \%(593)$ & $46.2-51.9$ & $32.1 \%(388)$ & $29.5-34.8$ & $8.2 \%(99)$ & $6.7-9.9$ & $8.8 \%(106)$ & $7.2-10.5$ \\
\hline$P$ value & $p=0.000$ & & $p=0.000$ & & $p=0.023$ & & $p=0.053$ & & $p=0.000$ \\
\hline
\end{tabular}

${ }^{*} P<0.05,{ }^{* *} P<0.001$

$P$ value according to the Chi-square tests. 
Table 5 - Food Insecurity prevalence in Portugal by health region in $2013 \quad(n=1382)$

\begin{tabular}{lccccccccccc} 
& \multicolumn{2}{c}{ Food Security } & \multicolumn{2}{c}{ Food Insecurity } & \multicolumn{2}{c}{ Low Food Insecurity } & \multicolumn{2}{c}{ Moderate Food Insecurity } & \multicolumn{2}{c}{ Severe Food Insecurity } \\
& $\%(n)$ & $95 \% \mathrm{Cl}$ & $\%(n)$ & $95 \% \mathrm{Cl}$ & $\%(n)$ & $95 \% \mathrm{Cl}$ & $\%(n)$ & $95 \% \mathrm{Cl}$ & $\%(n)$ & $95 \% \mathrm{Cl}$ \\
Alentejo & $53.5 \%(46)$ & $42.4-64.3$ & $46.5 \%(40)$ & $35.7-57.6$ & $31.4 \%(27)$ & $21.8-42.3$ & $10.5 \%(9)$ & $4.9-18.9$ & $4.7 \%(4)$ & $1.3-11.5$ \\
Algarve & $40.5 \%(83)$ & $33.7-47.5$ & $59.5 \%(122)$ & $52.5-66.3$ & $31.7 \%(65)$ & $25.4-38.5$ & $12.7 \%(26)$ & $8.5-18.0$ & $15.1 \%(31)$ & $10.5-20.8$ \\
Centro & $50.0 \%(167)$ & $44.5-55.5$ & $50.0 \%(167)$ & $44.5-55.5$ & $39.2 \%(131)$ & $34.0-44.7$ & $7.2 \%(24)$ & $4.7-10.5$ & $3.6 \%(12)$ & $1.9-6.2$ \\
LVT & $42.1 \%(101)$ & $35.8-48.6$ & $57.9 \%(139)$ & $51.4-64.2$ & $37.9 \%(91)$ & $31.8-44.4$ & $12.5 \%(30)$ & $8.6-17.4$ & $7.5 \%(18)$ & $4.5-11.6$ \\
Norte & $54.9 \%(284)$ & $50.5-59.3$ & $45.1 \%(233)$ & $40.7-49.5$ & $28.4 \%(147)$ & $24.6-32.5$ & $9.9 \%(51)$ & $7.4-12.8$ & $6.8 \%(35)$ & $4.8-9.3$ \\
Total & $49.3 \%(681)$ & $46.6-51.9$ & $50.7 \%(701)$ & $48.1-53.4$ & $33.4 \%(461)$ & $30.9-35.9$ & $10.1 \%(140)$ & $8.6-11.8$ & $7.2 \%(100)$ & $5.9-8.7$ \\
\hline$P$ value & $p=0.001$ & & $p=0.001$ & & $p=0.009$ & & $p=0.186$ & & $p=0.000$ \\
\hline
\end{tabular}

${ }^{*} P<0.05,{ }^{* *} P<0.001$

$P$ value according to the Chi-square tests.

Table 6 - Adjusted logistic regression analysis results of food Insecurity in Portugal by health region in $2011(n=1175)$

\begin{tabular}{|c|c|c|c|}
\hline & Food Insecurity & Moderate and Severe Food Insecurity & Severe Food Insecurity \\
\hline & $\operatorname{Exp}(B)$ (Odds ratio) & $\operatorname{Exp}(B)$ (Odds ratio) & $\operatorname{Exp}(B)$ (Odds ratio) \\
\hline Alentejo & $0.875(0.538-1.424)$ & $1.394(0.759-2.559)$ & $1.341(0.470-3.827)$ \\
\hline Algarve & $2.111\left(1.344^{-3}-316\right)^{*}$ & $2.482(1.434-4.297)^{*}$ & $4.083(1.829-9.115)^{*}$ \\
\hline Centro & $1.233(0.832-1.827)$ & $0.896(0.517-1.552)$ & $1.733(0.731-4.108)$ \\
\hline LVT & $1.888(1.303-2.736)^{*}$ & $1.784(1.113-2.857)^{*}$ & $1.794(0.835-3.857)$ \\
\hline Norte & Ref. & Ref. & Ref. \\
\hline
\end{tabular}

Ref., referent category

Adjusted for respondent age, sex of the respondent, highest level of respondent education, occupational status of the respondent, nationality, presence of children in household, family size and number of members in the household with income

${ }^{*} P<0.05,{ }^{* *} P<0.001$

Table 7 - Adjusted logistic regression analysis results of food Insecurity in Portugal by health region in 2012 $(n=1208)$

\begin{tabular}{|c|c|c|c|}
\hline & Food Insecurity & Moderate and Severe Food Insecurity & Severe Food Insecurity \\
\hline & $\operatorname{Exp}(B)$ (Odds ratio) & $\operatorname{Exp}(B)$ (Odds ratio) & $\operatorname{Exp}(B)$ (Odds ratio) \\
\hline Alentejo & $0.660(0.416-1.046)$ & $0.818(0.448-1.494)$ & $1.083(0.508-2.307$ \\
\hline Algarve & $4.657(2.151-10.081)^{* *}$ & $11.150(5.306-23.429)^{* *}$ & $13.472(5.862-30.962)^{* *}$ \\
\hline Centro & $0.974(0.717-1.323)$ & $0.651(0.420-1.009)$ & $0.694(0.383-1.259)$ \\
\hline LVT & $1.505(1.017-2.227)^{*}$ & $0.976(0.586-1.627)$ & $0.728(0.849-1.516)$ \\
\hline Norte & Ref. & Ref. & Ref. \\
\hline
\end{tabular}

Ref., referent category

Adjusted for respondent age, sex of the respondent, highest level of respondent education, occupational status of the respondent, nationality, presence of children in household, family size and number of members in the household with income

${ }^{*} P<0.05,{ }^{* *} P<0.001$ 
Table 8 - Adjusted logistic regression analysis results of food Insecurity in Portugal by health region in 2013 $(\mathrm{N}=1382)$

\begin{tabular}{|c|c|c|c|}
\hline & $\begin{array}{l}\text { Food Insecurity } \\
\text { Exp (B) (Odds ratio) }\end{array}$ & $\begin{array}{l}\text { Moderate and Severe Food Insecurity } \\
\text { Exp (B) (Odds ratio) }\end{array}$ & $\begin{array}{l}\text { Severe Food Insecurity } \\
\text { Exp (B) (Odds ratio) }\end{array}$ \\
\hline Alentejo & $1.165(0.710-1.911)$ & $0.881(0.440-1.765)$ & $0.643(0.211-1.960)$ \\
\hline Algarve & $1.797(1.247-2.591)^{*}$ & $2.125(1.365-3.308)^{*}$ & $2.735(1.504-4.975)^{*}$ \\
\hline Centro & $1.271(0.939-1.722)$ & $0.568(0.357-0.903)^{*}$ & $0.426(0.199-0.909)^{*}$ \\
\hline LVT & $1.877(1.329-2.652)^{* *}$ & $1.349(0.861-2.113)$ & $1.128(0.581-2.188)$ \\
\hline Norte & Ref. & Ref. & Ref. \\
\hline
\end{tabular}

Ref., referent category

Adjusted for respondent age, sex of the respondent, highest level of respondent education, occupational status of the respondent, nationality, presence of children in household, family size and number of members in the household with income

${ }^{*} P<0.05,{ }^{* *} P<0.001$

For low FI, a significantly higher prevalence than the national average was found in Centro (39.2\%) and Lisboa and Vale do Tejo (37.9\%) and, a significantly lower prevalence was found in Norte (28.4\%), Alentejo (31.4\%) and Algarve (31.7\%). For severe FI a significantly higher prevalence, when comparing with the national average was found in Algarve (15.1\%) and in Lisboa and Vale do Tejo (7.5\%). For the other health regions, the prevalence of severe FI was significantly lower than the national average (Table 5). For the three years, Algarve (56.9\% in 2011, 77.1\% in 2012 and $59.5 \%$ in 2013) and Lisboa and Vale do Tejo $(51.6 \%$ in $2011,58.6 \%$ in 2012 e $57.9 \%$ in 2013 ) ranked first with regard to the prevalence of FI in Portugal. However, we found some differences in these two regions when we analysed FI by different categories. For Algarve and particularly regarding to the data from 2012 and 2013, we found a significantly higher prevalence than the national average for severe FI and a significantly lower prevalence than the national average for low FI. On the other hand, for Lisboa and Vale do Tejo a significantly higher prevalence than the national average was found for low FI. On the other hand, in 2011 and 2012 we found that Alentejo (42.5\% in 2011 and $43.8 \%$ in 2012) was the region with lower FI prevalence and in 2013, Norte ( $45.1 \%$ in 2013) had the lowest prevalence of FI.

Even after adjusting for the potential confounders (tables 6 to 8), significant differences were found in FI across health regions. In 2011, a significantly association was found between FI (for all categories of FI) and health region. Comparing with the households living in the Norte region, a higher risk of FI was found in households living in Algarve (OR=2.111; 95\%IC 1.344-3.316) and Lisboa and Vale do Tejo (OR=1.888; 95\%CI 1.303-2.736) regions. When we analysed the moderate and severe FI levels we found the same association. For the extreme level of FI (severe FI) this higher risk was observed only for the households living in Algarve region (OR=4.083; 95\%CI 1.829-9.115).

Data from Infofamília Survey 2012 also showed a significant association between FI and health region of Portugal. A higher risk for FI was found in households living in Algarve (OR=4.657; 95\%CI 2.151-10.081) and Lisboa and Vale do Tejo (OR=1.505; 95\%CI 1.017-2.227), comparing with those living in the Norte region. A higher risk for moderate and severe FI was also found in households living in Algarve.

Data from the Infofamilia 2013 Survey also found a higher risk of FI, independent of the FI level for households living in the Algarve region. However, for households living in Lisboa and Vale do Tejo region (OR=1.877; 95\%CI 1.329-2.652) a higher risk of FI was found just for the overall level of FI. For the extreme levels of FI (moderate and severe FI and severe FI), a lower risk was found for households living in Centro. 


\section{Discussion and conclusions}

The main focus of this study was to examine FI prevalence in Portugal during the economic crisis and to identify disparities across health regions. Our results suggest that the prevalence of FI was relatively unchanged at national and regional levels, during the analysis period (2011-2013). The changes observed during these three years were not statistically significant, meaning that sampling variation might explain the differences observed in the obtained results. Considering the results from the three independent samples per year, they also showed an overall remarkable consistency. Additionally, the most recent data, from 2013, indicates a high prevalence of FI (50.7\%). However it is important to take into account that the majority of food-insecure households (33.4\%) are in the less severe level - low FI - meaning that the respondents, at least, had anxiety about accessing adequate food or had reduced the quality of their food intake, without substantially reducing their food quantity. On the other hand, moderate and severe FI levels indicate situations where the quantity of food intake was reduced because the household have lack of resources to acquire food. This situation seems to exist in $17.3 \%$ of the Portuguese sample analysed.

As we know, few studies have been conducted in Portugal on FI. The first explanatory study in this field was conducted in 2003, reporting a prevalence of $8.1 \%$ of household FI (Branco et al., 2003). Most recently, data from the last Portuguese National Health Survey estimated a prevalence of $16.7 \%$ for household FI between 2005 and 2006 (Álvares, 2013). Comparing to these results, our study found a much higher prevalence for this household condition (50.7\%). However, our results cannot be directly comparable with these data because different methodological approaches were used, both with regard to the sampling method and to the data collection tool. In the study conducted in 2003 in Portugal, a very brief indicator of FI was used, in which this condition was evaluated with a food sufficiency question ("During the last 30 days, did you change the consumption of any essential food because of economic constraints?") (Branco et al., 2003). The Portuguese National Health Survey applied the United States Department of Agriculture (USDA) Six-Item Short Form of the Food Security Survey Module (Álvares, 2013). Thus, the tools used by the previous studies to measure household FI in Portugal didn't capture the lower level of severity measured by our tool (worrying about running out of food). On the other hand, our data were derived from a sample of the Portuguese population that frequent the National Health System (Health Centres). As we use a non-representative sample of the Portuguese population, it is not possible to generalize these data for the entire Portuguese population. Additionally, the data collection period of our study coincided with the great economic crisis in Portugal, which can in part explain the higher prevalence found. It is worth noting that the concept of FI assessed in this study (using a household food insecurity scale) is based on individual perception concerning the household difficulties with food access, which could differ in comparison to the real situation of household FI. Low FI level is the one most affected by individual perception, because it at least represents the individual anxiety about uncertainty for food access. Indeed, according to our results, this level represents the majority of Portuguese food-insecure households. It is possible that the current economic crisis and that the individual perception of times of political, social and economic instability may have contributed to the increased perceived risk of FI.

The prevalence of FI found in our study was also higher than the estimated rates obtained with similar questionnaires in other countries, such as the USA, Canada, Brazil and France. For the USA, a prevalence of $14.5 \%$ of food insecurity was found in 2012 (Coleman-Jensen et al., 2013), 12.6\% in Canada in 2012 (Tarasuk et al., 2014), 30.2\% in Brazil in 2009 (IBGE, 2010) and 12.0\% in France in 2006-2007 (Darmon et al., 2011). The highest prevalence of FI observed in Portugal, comparing with prevalence observed in the other countries above described can be associated with the great economic depression and social instability that Portugal was experiencing during the period of data collection, which could easily affect the individuals' perception about their households financial insecurity situation. However, the comparison with results of other countries is also not feasible considering the different metho- 
dological approaches used, the different social, economic, political and cultural contexts of respective countries and the time differences of the reviewed studies. It is also important to take into account that Portugal is one of the OECD countries with highest levels of income inequalities. In 2010, the OECD estimated that the Gini coefficient (one of the most important indicators of inequalities of income distribution) was 30.3\%, 32.0\%, 34.4\% and 38.0\% in France, Canada, Portugal and USA, respectively (Oecd Statextracts, 2010).

Furthermore, disparities according to health region were found for household FI in Portugal. Our data showed that Algarve and Lisboa and Vale do Tejo were the two regions with the highest levels of FI. Even after controlling for the potential effects of socioeconomic variables that may influence FI, the households living in Algarve and Lisboa and Vale do Tejo regions were likely to have a higher risk for FI.

FI disparities among regions, found in our study, can be explained by the different social, political, economic contexts, by the local food environments and as well as by the household characteristics of the regions. Recent studies in the United States (US) suggested that socioeonomic contexts at regional level may be linked to household FI such as: local employment conditions, local living cost (housing costs), local wages averages, local food assistance programs and social assistance programs, local economy and social cohesion in the community. Local food environments, as the local food distribution systems and the availability of food stores in the neighborhood, also play an important role in the household FI and can also be responsible for the disparities across country region (Bartfeld and Dunifon, 2005; Bartfeld et al., 2006; Carter et al., 2014).

In Portugal, data from the National Census (National Household Survey on demographic, social and economic issues) in 2011, reveal some social and economic characteristics of the Algarve and Lisboa and Vale do Tejo regions that could be linked with the highest levels found for FI in these regions. Portugal is a relatively small country but large discrepancies are visible between the country's regions. According to the National Census 2011 data, these two regions were in the forefront for the prevalence of some of the social and economic characteristics, such as a high proportion of monoparental families, a high proportion of foreign citizens and also ranked highest in the average rental cost for housing (Portugal, 2012b, 2012d).

In 2011, a higher prevalence of monoparental families, which are recognized to be a vulnerable social group (Rosier, 2011; USDA, 2012), was found in Lisboa (18.2\%) and in Algarve (16.3\%), when comparing to the national average (14.9\%). Moreover, it was also reported by the National Census of 2011 that unemployment affects $15.1 \%$ of these monoparental families (Portugal, 2013). A higher percentage of minority groups such as migrant populations were also found in the Algarve as well as in Lisboa. According to these data, Algarve is the Portuguese region with the highest prevalence of foreign citizens (11.6\%) when compared to the national average (3.74\%). For Lisboa region, the prevalence of citizens from other nationalities was also higher (7.2\%) than the national average. Furthermore, $17.9 \%$ of Algarve's population had already lived away from the country at least for one year, representing also a higher prevalence than the national average (13.2\%) (Portugal, 2012a, 2012b, 2012d). Indeed, migrant populations have been also considered as socially vulnerable groups and different studies suggest that a migrant populations are likely to have a higher risk of FI (Hill et al., 2011; Quandt et al., 2004). According to Hill et al., it was estimated that migrant individuals had a prevalence of FI more than 4 times greater than the general US population (Hill et al., 2011). In our study, in spite of having a very low percentage of foreign citizens (1.8\%), we found that foreign respondents were more prevalent in the Algarve (31.8\%) and Lisboa $(25.8 \%)$ regions.

Furthermore, Algarve and Lisboa have been described as the Portuguese regions with the largest proportion of the population born in another part of the country (Gomes et al., 2013). Indeed, the internal migratory flows in Portugal are characterized by a rural depopulation (an internal migration to more urbanized areas) and also an internal migration from the interior to coastline regions, particularly to the capital city (Lisboa) and the Algarve, and these migratory dynamics largely affect the characteristics of the population living in these regions (Rees et al., 1998). Therefore, these population groups are less 
likely to have family and community/social support, which can have an important role in the household's ability to face FI. These social support networks might provide financial and emotional support, which can impact the vulnerability to FI. Different studies also suggest that friends and family support have been recognized as an important coping strategy to deal with FI (Bartfeld and Dunifon, 2005; Bartfeld et al., 2006). The presence of social networking seems to be less evident in these Algarve and Lisboa communities. Furthermore, the internal migratory flows from rural areas to coastline and urban areas foster the distance between these populations and agriculture issues, which can also be important as a coping strategy to deal with situations of FI. These conditions may, in large part, determine the adaptive capabilities of these population groups to response to situations of FI risk, becoming more vulnerable to this situation.

Living costs are also expected to play an important role. There is substantial geographic variation in housing costs and this has important implications for the household economic situation. In 2011, the average rental cost for housing was 291 and 269 euro in Algarve and Lisbon respectively, higher values in comparison to national average (235 euro). Moreover, during the last decade, the increasing trend in average rental cost for housing was also higher than the national average for these two regions (Portugal, 2012b, 2012d).

It is also generally accepted that job availability and working conditions are crucial to ensure food security, because of their direct impact on household income. Regarding the unemployment rate, Algarve in 2011 presented a high prevalence (15.7\%), higher than the national average (13.2\%). However, a lower prevalence of unemployment rate was found in Lisboa (12.9\%), compared to the national average (15.7\%) (Portugal, 2012b, 2012d).

When we looked at the social inequalities indicators, according to data from a national survey on the structure of the expenditures and the income distribution of the households living in Portugal during 2010-2011, we found that Lisboa showed the highest values for these indicators (Gini coefficient of $37.1 \%)$. Lisboa is the only region in the country that presents higher social indicator levels in comparison to the national average. By contrast, we found that Alentejo (29.2\%) and Algarve (28.4\%) were the regions with the lower levels for social inequalities indicators. Regarding the relative position for the poverty indicators, the differences are also significantly across regions. Algarve (11.3\%), Lisboa (14.2\%) and Centro (14.8\%) were the regions with lower levels for "at risk of poverty rate", lower than the national average (Portugal, 2012e). Therefore, we found that Lisboa is at the same time the region with the highest level of income inequality distribution and the lowest level for poverty indicators. On the other hand, Algarve presented lower levels for both, poverty and social inequalities indicators, compared to the national average.

The social and economic context of Algarve and Lisbo and Vale do Tejo, previously described, could be linked with the higher prevalence of FI found for these regions. However, it sounds contradictory that these two regions present at the same time the lowest levels for poverty indicators and the highest levels for FI, in comparison to the national average. As known, household FI is not a condition just observed in families who are below the poverty line. Those families who are not necessary considered as poor but are recently facing some situation of financial insecurity, usually called as "economic shocks" and caused by recent economic changes in the household (recent unemployment situation, household income reduction and lost of social support benefits), can be in a more vulnerable situation for FI. It is supposed that those families might have less adaptive capabilities to deal with situations of FI (Leete and Bania, 2010).

Moreover, in the Algarve, tourism and related services are the main driving forces of all economic activity. The seasonal nature of this economic sector can very negatively affect the economic activity of the region, particularly in areas like business and employment, which can greatly affect the food security of its population. This economic sector was also the most affected by the unemployment rate, due to the current economic crisis (CCDR, 2012).

Additionally, our findings also suggest that the Centro region is becoming a less vulnerable region for household FI over the period of analysis, especially if we look for the most severe levels of FI (moderate and severe FI). Indeed, data from the 
2011 Census for the Centro region showed a lower proportion of monoparental families and lower proportion of foreign citizens, than the national average. Furthermore, a higher proportion of older people was also found in this region when compared to the national average (Portugal, 2012C). These socio-demographic characteristics of the Centro region might explain in part the lower levels of FI found for this region. Unfortunately, we could not test any of these hypotheses.

However our results should be carefully analyzed, considering the limitations of this study. Based on sample size variations, the comparisons done between the different years of analysis could be not precise. Likewise, the sample size variations are a limitation in the comparisons done between health regions. In spite of this study having been developed at the national level, the sample selected was not representative of the Portuguese population. Therefore, the prevalence estimated for FI is not necessarily generalizable to the entire Portuguese population. As well, response bias may have occurred because we used a self-reported measure of FI. Lastly, the tool applied to measure FI provided data at the household level, in which each household member may be affected differently by the household's FI. Moreover, since this study is a cross-sectional study design, no causal relationships can be established.

The presence of such high levels of FI in Portugal and the identification of different profiles across regions show the need to consider FI as a public health challenge. Portugal is one of the EU countries with the highest inequality and it is only expected to get worse, because of fiscal pressures, Portugal is making severe cuts on social assistance policies, on many public services and also in wages of public sector workers imposed by the IMF. All these political, social and economic changes could have an impact in the vulnerability to FI of the Portuguese population. Thus, the continuous monitoring of FI situation in the Portuguese population is essential to identify groups at risk of FI and to guide decision-making in order to mitigate their impact on the populations' health. Monitoring FI at local level, with the collaboration of municipalities and local social institutions, should be considered as future strategy to be implemented. The tool applied in our study to evaluate household FI is a very simple tool that can be easily used by different professionals. The results of this study also suggest the need for responses addressing the food security concerns, at regional and local level, in particular those ones more affected by this problem (Algarve and Lisboa and Vale do Tejo), based on a broader action involving the different policy sectors, such as health, social security, municipalities and local institutions in the field of social economy. Considering the strengths and limitations of this study, we believe that it will contribute to the knowledge and characterization of the FI situation in Portugal, in particular during the current economic crisis, mainly in the period of IMF financial assistance program in Portugal.

\section{Acknowledgments}

The authors would like to thank to all nurses in primary health care (Linha Saúde 24) for their support in data collection and also to the team from Directorate-General of Health for their support for INFOFAMÍLIA Survey and Luiza Kent-Smith for the English language revision of this paper.

\section{Authors' Contribution}

All authors contributed equally to this work. Graça, Nogueira and Gregório designed the study. Nogueira and Gregório analyzed the data. Gregório interpreted the data and wrote the paper. Costa gave scientific support and revised the manuscript. All authors discussed the results and implications and commented on the manuscript at all stages.

\section{References}

ÁLVARES, L. M. M. Factors associated with food insecurity in the Portuguese population. 2013. Dissertação (Mestrado em Nutrição Clínica) Faculdade de Ciências da Nutrição e Alimentação da Universidade do Porto, Porto, 2013.

BARTFELD, J.; DUNIFON, R. State-level predictors of food insecurity and hunger among household with children. Madison; Ithaca. United States Department of Agriculture. Economic Research Service, 2005. Disponível em: <https://www.idph. state.ia.us/hpcdp/common/pdf/food_security/ state_level_fs.pdf $>$. Acesso em: 10 out. 2014. 
BARTFELD, J. et al. What factors account for stateto-state differences in food security? Washington, DC: United States Department of Agriculture. Economic Research Service, 2006. Disponível em: <http://www.ers.usda.gov/media/86o374/ eib2o_002.pdf>. Acesso em: 10 ago. 2014.

BRANCO, M. J.; NUNES, B.; CANTREIRAS, T. Uma observação sobre "insegurança alimentar". Lisboa: Instituto Nacional de Saúde Dr. Ricardo Jorge, 2003.

CARTER, M. A.; DUBOIS, L.; TREMBLAY, M.

S. Place and food insecurity: a critical review and synthesis of the literature. Public Health Nutrition, Wallingford, v. 17, n. 1, p. 94-112, 2014.

CAVERO, T.; POINASAMY, K. A cautionary tale: the true cost of austerity and inequality in Europe. Oxford: Oxfam GB, 2013.

CCDR ALGARVE - COMISSÍO DE COORDENAÇÃO E DESENVOLVIMENTO REGIONAL DO

ALGARVE. Algarve region: the Algarve in Portugal and Europe. Faro, 2012. Disponível em: <http://s3platform.jrc.ec.europa.eu/ documents/10157/187136/ALGARVE\%20 REGIONv2.pdf $>$. Acesso em: 10 ago. 2014.

COLEMAN-JENSEN, A.; NORD, M.; SINGH, A. Household food security in the United States in 2012, ERR-155. Washington, DC: United States Department of Agriculture. Economic Research Service, 2013. Disponível em: <http://www.ers. usda.gov/media/1183208/err-155.pdf >. Acesso em: 1 out. 2014 .

\section{CEC - COMMISSION OF THE EUROPEAN} COMMUNITIES. White paper "together for health: a strategic approach for the EU 2008 - 2013. Brussels, 2007. Disponível em: <http://ec.europa. eu/health-eu/doc/whitepaper_en.pdf $>$. Acesso em: 1 out. 2014 .

DARMON, N.; DREWNOWSKI, A. Does social class predict diet quality? American Journal of Clinical Nutrition, Bethesda, v. 87, p. 1107-1117, 2008.

DARMON, N. et al. Food and nutrient intakes of food insecure people in France. Annals of Nutrition \& Metabolism, New York, v. 53, p. 177, 2011. Supplement 3.
DI MEGLIO, E. Population and social conditions: living standards falling in most member States. Eurostat Statistics in focus, Luxembourg, v. 8, n. 8, p. 1-8, 2013.

DORE, A. R.; ADAIR, L. S.; POPKIN, B. M. Low income Russian families adopt effective behavioral strategies to maintain dietary stability in times of economic crisis. Journal of Nutrition, Rockville, v. 133, n. 11, p. 3469-3475, 2003.

DREWNOWSKI, A. Obesity, diets, and social inequalities. Nutrition Reviews, Washington, D.C., v. 67, n. 1, p. S36-S39, 2009.

EUROSTAT. Unemployment statistics. [S.l.], 2013. Disponível em: <http://epp.eurostat.ec.europa.eu/ statistics_explained/index.php/Unemployment_ statistics $>$. Acesso em: 29 jul. 2014.

EVANS, J. M. M. et al. Socio-economic status, obesity and prevalence of type 1 and type 2 diabetes mellitus. Diabetic Medicine, Chichester, v. 17 , n. 6 , p. $478-480,2000$.

GOMES, M. C. S.; MOREIRA, M. J. G.; PINTO, M. L. R. Movimentos migratórios internos em Portugal, considerando grupos de idades, níveis de habilitações académicas e atividade (2001-1995). In: CONGRESSO ASSOCIAÇÃO DE DEMOGRAFIA HISTÓRICA, 10, 2013, Albacete. Livro de resumos. Madrid: Associação da Demografia Histórica, 2013. Disponível em: <https://www.adeh.org/?q=es/ system/files/xcongreso/Sesión34/Ponencias\%20 completas/gomes_pinto_y_moreira_movimientos_ migratorios_internos_em_portugal_sesion_34. pdf $>$. Acesso em: 21 jul. 2014.

GRAÇA, P. et al. Portugal: alimentação saudável em números 2013: Programa Nacional para a Promoção da Alimentação Saudável. Lisboa: Direção-Geral da Saúde, 2013. Disponível em: <http://www.dgs.pt/estatisticas-de-saude/ estatisticas-de-saude/publicacoes/portugalalimentacao-saudavel-em-numeros-2013.aspx>. Acesso em: 1 out. 2014.

HILL, B. G. et al. Prevalence and predictors of food insecurity in migrant farmworkers in Georgia. American Journal of Public Health, New York, v. 101, n. 5, p. 831-833, 2011. 
IBGE - INSTITUTO BRASILEIRO DE GEOGRAFIA E ESTATÍSTICA. Pesquisa nacional por amostra de domicílios: segurança alimentar 2004-2009. Rio de Janeiro, 2010.

PORTUGAL. INSTITUTO NACIONAL DE ESTATÍSTICA. Censos 2011 resultados definitivos: Portugal. Lisboa, 2012a.

PORTUGAL. INSTITUTO NACIONAL DE

ESTATÍSTICA. Censos 2011 resultados definitivos: região Algarve. Lisboa, 2012b.

PORTUGAL. INSTITUTO NACIONAL DE

ESTATÍSTICA. Censos 2011 resultados definitivos: região Centro. Lisboa, 2012c.

PORTUGAL. INSTITUTO NACIONAL DE

ESTATÍSTICA. Censos 2011 resultados definitivos: região Lisboa. Lisboa, 2012d.

PORTUGAL. INSTITUTO NACIONAL DE ESTATÍSTICA. Inquérito às despesas das famílias 2010/2011. Lisboa, 2012e.

PORTUGAL. INSTITUTO NACIONAL DE ESTATÍSTICA. Famílias nos censos 2011:

diversidade e mudança: como evoluíram as famílias em Portugal? Lisboa, 2013.

PORTUGAL. INSTITUTO NACIONAL DE

ESTATÍSTICA. Inquérito às condições de vida 2013 (dados provisórios). Lisboa, 2014.

LEETE, L.; BANIA, N. The effect of income shocks on food insufficiency. Review of Economics of the Household, Norwell, v. 8, n. 2, p. 505-526, 2010.

MARMOT, M.; WILKINSON, R. Social determinants of health. 2. ed. New York: Oxford University Press, 2005.

OECD STATEXTRACTS. Income distribution and povert: Gini (at disposable income, post taxes and transfers). [S.l.], 2010. Disponível em: <http:// stats.oecd.org/index.aspx?queryid=46022 $>$. Acesso em: 12 jun. 2014.

QUANDT, A. S. et al. Household food security among migrant and seasonal latino farmworkers in North Carolina. Public Health Reports, Washington, DC, v. 119, n. 6, p. 568-576, 2004.
REES, P. et al. Internal migration and regional population dynamics in Europe: Portugal case study. Leeds, University of Leeds, School of Geography, 1998. Working paper.

ROBERTSON, A. Social inequalities and the burden of food-related ill-health. Public Health Nutrition, Wallingford, v. 4, n. 6a, p. 1371-1373, 2001.

ROBERTSON, A.; LOBSTEIN, T.; KNAIS, C. Obesity and socio-economic groups in Europe: evidence review and implications for action. European Commission Directorate General for Health and Consumers, 2007. Disponível em: <http:// ec.europa.eu/health/social_determinants/docs/ report_healthinequalities_swd_2013_328_en.pdf>. Acesso em: 14 abr. 2014.

ROOKS, R. N. et al. The association of race and socioeconomic status with cardiovascular disease indicators among older adults in the health, aging and body composition study. Journals of Gerontology, Series B: Psychological Sicences and Social Sciences, Washington, DC, v. 57, n. 4, p. S247-S256, 2002.

ROSIER, K. Food insecurity in Australia: what is it, who experiences it and how can child and family services support families experiencing it?. Melbourne, Australian Institute of Family Studies, 2011.

SINGH, G. K.; SIAHPUSH, M.; KOGAN, M. D. Rising social inequalities in US childhood obesity, 20032007. Annals of Epidemiology, New York, v. 20, n. 1, p. 40-52, 2010.

SOBAL, J.; STUNKARD, A. J. Socioeconomic status and obesity: a review of the literature. Psychological Bulletin, Washington, DC, v. 105, n. 2, p. 260-275, 1989.

STUFF, J. E. et al. Household food insecurity is associated with adult health status. The Journal of Nutrition, Rockville, v. 134, n. 9, p. 2330-2335, 2004. 
TARASUK, V.; MITCHELL, A.; DACHNER, N. Household food insecurity in Canada, 2012. Toronto: Research to identify policy options to reduce food insecurity (PROOF), 2014. Disponível em: <http://nutritionalsciences.lamp.utoronto.ca/ wp-content/uploads/2014/o5/Household_Food_ Insecurity_in_Canada-2012_ENG.pdf $>$. Acesso em: 20 ago. 2014.

USDA - UNITED STATES DEPARTMENT OF AGRICULTURE, ECONOMIC RESEARCH SERVICE. Food insecurity rates are high for single-mother households and lower for households with elderly. [S.I.], 2012. Disponível em: <http://www. ers.usda.gov/data-products/chart-gallery/detail. aspx? chartId=40103 - .U6IH7KDoD4M >. Acesso em: 20 jul. 2014.

WARD, E. et al. Cancer disparities by race/ ethnicity and socioeconomic status. Cancer Journal for Clinicians, Hoboken, v. 54, n. 2, p. 78 93, 2004.

WORLD FOOD SUMMIT. Declaração de Roma sobre a segurança alimentar e plano de ação da cimeira mundial de alimentação. Roma, 1996. Disponível em: <http://www.fao.org/docrep/oo3/ W3613P/W3613Poo.HTM>. Acesso em: 7 jun. 2014.
WHO (Europe) - WORLD HEALTH ORGANIZATION REGIONAL OFFICE FOR EUROPE. Health 2020: a European policy framework supporting action across government and society for health and well-being. Copenhagen, 2012. Disponível em: <http://www.euro.who.int/_data/assets/ pdf_file/o020/170093/RC62wdo8-Eng.pdf?ua=1>. Acesso em: 20 jul. 2014 .

WHO (Europe) - WORLD HEALTH ORGANIZATION REGIONAL OFFICE FOR EUROPE. Vienna Declaration on Nutrition and Noncommunicable Diseases in the Context of Health 2020. Vienna, 2013a. Disponível em: <http://www.euro.who. int/_data/assets/pdf_file/ooog/193878/ViennaDeclaration.pdf $>$. Acesso em: 20 jul. 2014.

WHO (Europe) - WORLD HEALTH ORGANIZATION REGIONAL OFFICE FOR EUROPE. European Food and Nutrition Action Plan 2015-2020. Copenhagen, 2013b. Disponível em: <http://www.euro.who. int/_data/assets/pdf_file/ooo8/253727/64wd14e_ FoodNutAP_140426.pdf >. Acesso em: 1 out. 2014.

Received: 03/09/2014

Approved: 24/09/2014 